\title{
First record of an introduced population of the southern lineage of white-clawed crayfish (Austropotamobius 'italicus') north of the Alps
}

\author{
C. Chucholl(1),^, A. Mrugała ${ }^{(2)}$, A. Petrusek ${ }^{(2)}$
}

Received November 14, 2014

Revised January 31, 2015

Accepted February 6, 2015

Key-words:

Non-indigenous

species,

DNA barcoding,

Austropotamobius

pallipes,

Species

complex,

Translocation

\section{ABSTRACT}

Elucidating the status of populations of endangered species of unclear origin may have important implications for conservation management. In September 2013, a population of white-clawed crayfish was discovered outside of the native range in a small artificial lake in the River Neckar catchment in southwestern Germany. White-clawed crayfish comprise two distinct lineages of yet unresolved taxonomic status, of which only the western lineage (Austropotamobius pallipes s. str.) is native to Germany. To clarify the taxonomic identity and origin of the newly discovered population, we evaluated diagnostic morphological characters and sequences of two mitochondrial genes (for 16S rRNA and cytochrome c oxidase subunit I) from two crayfish specimens. Both analyses concordantly assigned the crayfish to the southern lineage ( $A$. 'italicus'), with the closest matching haplotypes originating from northwestern Italy, southeastern Switzerland, and Lake Plansee in Austria, where an abundant introduced population of this lineage is present. The artificial lake in Germany was reportedly stocked with freshwater mussels from this Austrian lake. It thus appears likely that $A$. 'italicus' was introduced intentionally or accidentally during the process. Austropotamobius 'italicus' does not naturally occur north of the Alps and thus represents a non-native taxon for Germany, a fact to be considered in its management.

RÉSUMÉ

Premier signalement d'une population introduite de la lignée sud de l'écrevisse à pattes blanches (Austropotamobius 'italicus') au nord des Alpes

Mots-clés :

Espèce

non-indigène,

Code-barre

$A D N$,

Élucider l'état des populations d'espèces menacées d'origine incertaine peut avoir des implications importantes pour la gestion de la conservation. En septembre 2013, une population d'écrevisses à pattes blanches a été découverte à l'extérieur de l'aire de répartition naturelle dans un petit lac artificiel dans le bassin versant de la rivière Neckar, dans le sud-ouest de l'Allemagne. L'écrevisse à Austropotamobius pattes blanches comprend deux lignées distinctes de statut taxonomique non enpallipes, Complexe d'espèces, Translocation core résolu, dont seule la lignée occidentale (Austropotamobius pallipes s. str.) est originaire d'Allemagne. Pour clarifier l'identité taxonomique et l'origine de la population nouvellement découverte, nous avons évalué les caractères morphologiques diagnostics et les séquences de deux gènes mitochondriaux (pour le 16S rRNA

(1) Fisheries Research Station Baden-Württemberg, Argenweg 50/1, 88085 Langenargen, Germany

(2) Department of Ecology, Faculty of Science, Charles University in Prague, Viničná 7, 12844 Prague 2, Czech Republic

* Corresponding author: cchucholl@aol.com 
et la cytochrome c oxydase sous-unité I) de deux spécimens d'écrevisses. Les deux analyses sont concordantes et affectent l'écrevisse à la lignée sud ( $A$. 'italicus'), avec les haplotypes correspondants les plus proches en provenance de I'Italie du nord-ouest, du sud-est Suisse, et du lac Plansee en Autriche, où une population introduite abondante de cette lignée est présente. Des moules d'eau douce de ce lac autrichien auraient été introduites dans ce lac artificiel en Allemagne. II semble donc probable que $A$. 'italicus' a été introduit intentionnellement ou accidentellement au cours du processus. Austropotamobius 'italicus' ne se trouve pas naturellement au nord des Alpes et représente ainsi un taxon non indigène pour l'Allemagne, un fait à prendre en compte dans sa gestion.

\section{INTRODUCTION}

Native freshwater crayfish species (Crustacea, Decapoda, Astacidae) belong among taxa of conservational importance in most European countries (Souty-Grosset et al., 2006), and management of their populations should be based on well-founded arguments. As such, elucidating the status of populations of unclear origin may have important implications for subsequent conservation actions.

In September 2013, a population of endangered white-clawed crayfish, Austropotamobius pallipes (Lereboullet, 1858), was unexpectedly reported from a small shallow lake in the headwater catchment of a small tributary stream of the River Neckar in southwestern Germany. White-clawed crayfish are the rarest native crayfish species in Germany, where they reach their northeastern distribution limit (Kouba et al., 2014) and are naturally restricted to a small region east and north of the River Rhine between Basel and slightly north of Freiburg (Chucholl and Dehus, 2011). The newly discovered occurrence is located outside of this well-defined native range and the lake is man-made, which clearly points to an introduced origin of this population.

Austropotamobius pallipes is considered a species complex comprising two genetically distinct lineages with an as-yet unresolved species status. Based on mtDNA analysis and morphological differences, Grandjean et al. (2000; 2002) proposed species level for the two clades: Austropotamobius pallipes for the western lineage, distributed in France, the UK, Ireland, southwestern Germany and northwestern Switzerland, as well as western Italy, and A. italicus for the southern lineage, which is present on the Iberian Peninsula, in southern France, southeastern Switzerland, Italy, Austria, Slovenia, and Croatia. Although this view was adopted in other studies (e.g., Fratini et al., 2005; Pedraza-Lara et al., 2010; Matallanas et al., 2011), there still exists some debate as to whether $A$. italicus should be elevated to species rank (e.g., Chiesa et al., 2011). For the purpose of the present study, we acknowledge the existence of two distinct clades with an as-yet unresolved taxonomic status. For consistency with previous studies, we refer to the western lineage as $A$. pallipes s. str. and to the southern lineage as $A$. 'italicus'.

As only the western lineage, i.e. A. pallipes s. str., is native to Germany (Grandjean et al., 2002; Trontelj et al., 2005), unravelling the taxonomic identity and possible origin of the newly discovered population in the River Neckar catchment is mandatory. These aspects are of fundamental importance from a conservational perspective, since a population of the native lineage of local origin may serve as a valuable donor stock for ongoing restocking efforts and may therefore require protection. A population of the non-native lineage, by contrast, should not be allowed to spread and may not be subjected to conservation efforts. This holds especially true in view of the relatively deep divergence between the two lineages.

The primary objective of this study was therefore to assign the newly discovered crayfish to one of the two white-clawed crayfish lineages, thus obtaining relevant information for further management recommendations for this population. For this purpose, we used two complementary approaches for identification, namely morphological and genetic analysis. The results provide a support for the hypothesis about the origin of this enigmatic population. 


\section{METHODS}

In October 2013, three adult specimens (two males and one female; carapace lengths $=44.6$, 53.8 , and $47.0 \mathrm{~mm}$ ) were collected from the artificial lake that harbours the population in question (district of Reutlingen; 1.4 ha; average depth of approximately $2.5 \mathrm{~m} ; 603 \mathrm{~m}$ a.s.l.). No larger sample size was taken because the white-clawed crayfish ( $A$. pallipes $\mathrm{s}$. str.) is a protected species that is considered as close to extinction in Germany (Chucholl and Dehus, 2011), and the taxonomic identity of the crayfish was not known at the time of collection.

Upon capture, crayfish were transported to the laboratory for examination of the most frequently reported diagnostic morphometric character, namely the ratio between acumen (rostrum tip) length and total rostrum length $(A / R)$ (Albrecht, 1982; Grandjean et al., 2000; 2002; Bertocchi et al., 2008a). Although there is high intra- and interspecific morphological variability among populations of the A. pallipes complex (Ghia et al., 2006), Bertocchi et al. (2008a) showed that the rostrum tip could be used to discriminate the two lineages (cf. Grandjean et al., 2000). Reference data for $A / R$ ratios of the two lineages were compiled from the literature (Albrecht, 1982; Grandjean et al., 2000, and citations therein). Additional reference measurements were taken from three preserved $A$. pallipes s. str. specimens that have been collected from different populations within the native range in Germany (all male, carapace lengths $=26.8,31.6$, and $44.2 \mathrm{~mm}$ ).

Since the phenotypic variability among white-clawed crayfish may render morphological identification uncertain (cf. Ghia et al., 2006; Bertocchi et al., 2008a), we also used DNA barcoding for non-ambiguous genetic identification. In particular, we obtained partial sequences of the mitochondrial genes for the 16S rRNA (further abbreviated as 16S) and cytochrome c oxidase subunit I (COI), which had been used in previous studies on diversity of Austropotamobius across Europe (e.g., Trontelj et al., 2005; Ghia et al., 2006; Pedraza-Lara et al., 2010). Total DNA was extracted from up to $40 \mathrm{mg}$ of muscle tissues of a walking leg using the DNeasy tissue kit (Qiagen) from two specimens from the newly discovered population (the larger male and the female) and three specimens from a population within the native range of $A$. pallipes in Germany (River Dreisam catchment, district of Breisgau-Hochschwarzwald). These specimens were included for comparison of the genetic markers, and to verify their classification as $A$. pallipes s. str.

For the amplification of a 468 base pairs (bp) fragment of 16S rRNA gene, we used the primer pair AR/BR (Palumbi et al., 1991). The polymerase chain reactions (PCR) were performed in a total volume of $25 \mu \mathrm{L}$ containing: $6 \mu \mathrm{L}$ of DNA template, $0.2 \mu \mathrm{M}$ of each primer, $1 \times$ PCR Buffer (Promega), $2.5 \mathrm{mM} \mathrm{MgCl}_{2}, 0.1 \mathrm{mM}$ dNTPs, $0.5 \mathrm{U}$ of DNA Taq polymerase (Promega). The PCR thermal protocol included: an initial denaturation at $90^{\circ} \mathrm{C}$ for $2.5 \mathrm{~min}, 10$ cycles of $92^{\circ} \mathrm{C}$ for $50 \mathrm{~s}, 48^{\circ} \mathrm{C}$ for $30 \mathrm{~s}, 72^{\circ} \mathrm{C}$ for $40 \mathrm{~s}$, and 30 cycles of $92^{\circ} \mathrm{C}$ for $30 \mathrm{~s}, 48^{\circ} \mathrm{C}$ for $40 \mathrm{~s}, 72{ }^{\circ} \mathrm{C}$ for $40 \mathrm{~s}$, followed by the final extension at $72{ }^{\circ} \mathrm{C}$ for $3 \mathrm{~min}$. For the amplification of the $648 \mathrm{bp}$ long COI fragment, the universal primer pair LCO1490/HCO2198 (Folmer et al., 1994) was used. The reactions were performed in a total volume of $25 \mu \mathrm{L}$ containing: $2 \mu \mathrm{L}$ of DNA template, $0.4 \mu \mathrm{M}$ of each primer, 1x PCR Buffer (Promega), $2.2 \mathrm{mM} \mathrm{MgCl}_{2}, 0.15 \mathrm{mM}$ of dNTP, $1 \mathrm{U}$ of DNA Taq polymerase (Promega). The PCR thermal protocol included: an initial denaturation at $94{ }^{\circ} \mathrm{C}$ for $2.5 \mathrm{~min}, 35$ cycles of denaturing at $94{ }^{\circ} \mathrm{C}$ for $45 \mathrm{~s}$, annealing at $48{ }^{\circ} \mathrm{C}$ for $1 \mathrm{~min}$ and an extension at $72{ }^{\circ} \mathrm{C}$ for $1 \mathrm{~min}$, followed by the final extension at $72{ }^{\circ} \mathrm{C}$ for $10 \mathrm{~min}$. We then downloaded all relevant $\mathrm{CO}$ and $16 \mathrm{~S}$ Austropotamobius sequences from GenBank (not always overlapping the entire fragment obtained by us), and assessed the divergence between the newly obtained sequences and those most closely matching in GenBank. Due to variation of reference sequence length, we expressed the divergence in the number of differences (i.e. point mutations).

\section{RESULTS}

The morphological examination confirmed that the enigmatic crayfish belong to the $A$. pallipes species complex and suggested a position within the $A$. 'italicus' clade (Figure 1). The $A / R$ 

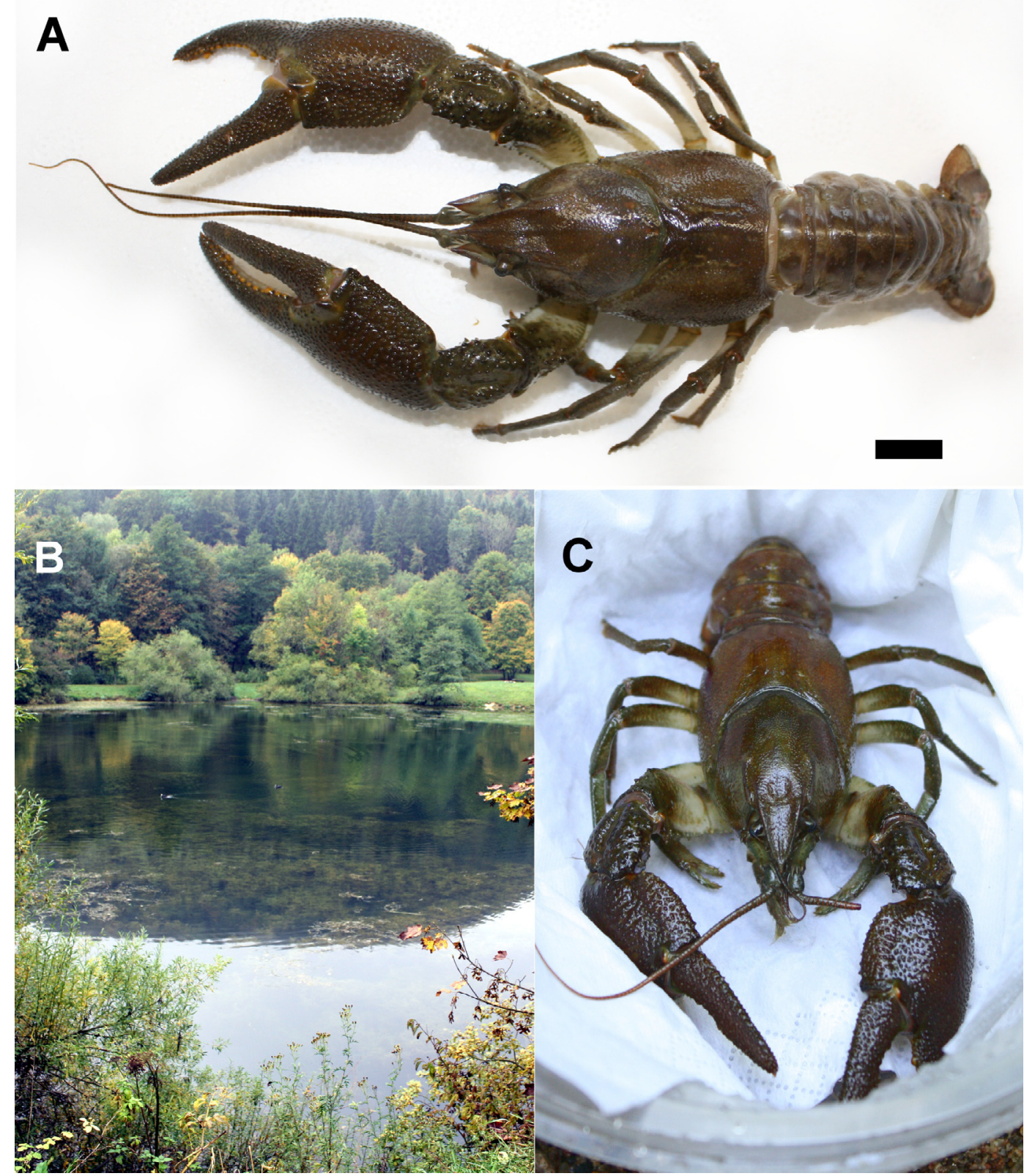

Figure 1

A - male A. 'italicus' specimen from the study population, $B$ - habitat of the study population, and $C-$ male $A$. pallipes s. str. specimen from the native German range for comparison. Although the rostrum tip could be used to discriminate the lineages (Figure 2), identification free of doubt was only obtained with DNA barcoding. Scale bar in A represents $10 \mathrm{~mm}$.

ratios of the examined specimens (mean $=0.34 \pm 0.06$ ) were consistently closer to reference values from $A$. 'italicus' ( 0.29 and 0.32$)$ than to values attributed to $A$. pallipes s. str. $(0.20$ and 0.22; Figure 2). Measurements of $A / R$ of the three reference specimens from the native German range, by contrast, were clearly in accordance with the known classification as A. pallipes s. str. (mean $A / R$ ratio $=0.22 \pm 0.04$ ). In addition to the high $A / R$ ratio, the live body colouration of two of the examined crayfish was conspicuously light-coloured and greyish, when compared to white-clawed crayfish from the native German range, which are typically browner in colouration. However, body colouration is rarely a diagnostic character in crayfish 


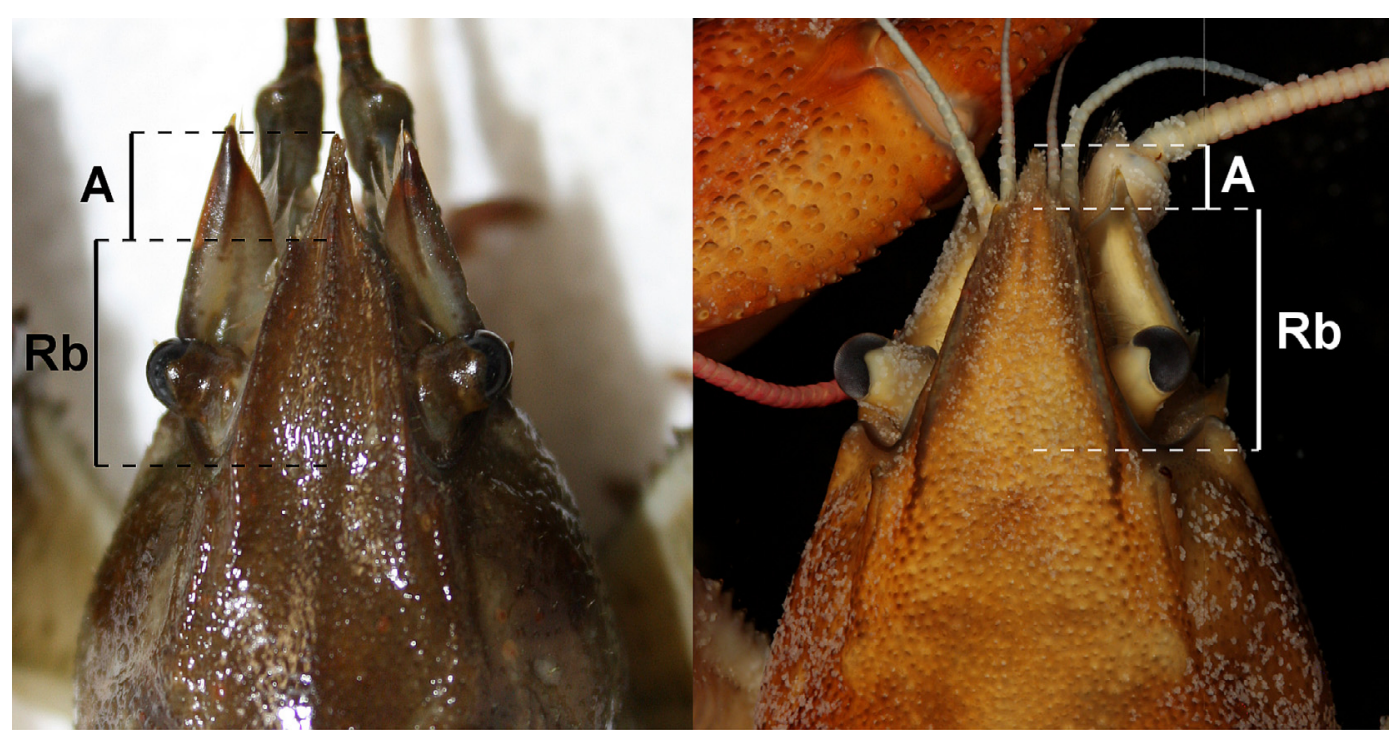

\section{Figure 2}

Comparison of rostrum shape between German specimens of A. 'italicus' (left) and A. pallipes s. str. (right). A denotes acumen length and $R b$ denotes length of the rostrum basis. The ratio $A / R$, with $R$ being total rostrum length $(A+R b)$, is typically larger in $A$. 'italicus'. The colouration of the right specimen has faded due to storage in ethanol.

and the larger male exhibited a slightly darker colouration, which was close to the body colour of German A. pallipes s. str. (Figures $1 \mathrm{~A}$ and $1 \mathrm{C}$ ).

All three genetically analysed white-clawed crayfish individuals from the native range in Germany were confirmed as $A$. pallipes s. str. From all specimens, we obtained an identical $\mathrm{COI}$ sequence matching exactly in the overlapping regions the publicly available sequences (GenBank accession nos. AY667115 and AF526891) from A. pallipes populations in central to eastern France, the UK, northwestern Italy, and southwestern Germany (Trontelj et al., 2005). Two distinct $16 \mathrm{~S}$ haplotypes (differing by a single indel in a variable poly-T region) were detected in the analysed $A$. pallipes s. str. individuals; their sequences exactly matched with, or slightly varied in such repetitive regions from, 16S haplotypes detected in Switzerland (Rhine and Rhône catchments; AJ242701-3; Largiadèr et al., 2000), France, and the introduced range in Ireland (AF237594-5; Grandjean et al., 2000).

In contrast, the $16 \mathrm{~S}$ and $\mathrm{COI}$ sequences obtained from the putative $A$. 'italicus' specimens from the German locality clearly indicated a different origin. The 16S fragment completely matched the reference $A$. 'italicus' sequences from the Po basin in northern Italy (AJ242705-7, AY521289, AY611183-5), the Magra river in northern Italy (AY611185, EU308125), the Rhine basin in southeastern Switzerland (AJ242705), and Lake Plansee in Austria (AJ242706) (Largiadèr et al., 2000; Zaccara et al., 2004; Fratini et al., 2005; Bertocchi et al., 2008b). Furthermore, several additional $A$. 'italicus' haplotypes from the Po basin in northern Italy (AY521290, AY611191), the Arno river in central Italy (HM622594), Lake Plansee (AF237600) as well as the Rhine basin in Switzerland (AJ242704) diverged by a single point mutation (Grandjean et al., 2000; Largiadèr et al., 2000; Zaccara et al., 2004; Fratini et al., 2005; Pedraza-Lara et al., 2010; Figure 3). The analyses of the COI fragment supported the former results. The most closely matching publicly available sequences (but of different fragment length), originating from the Po basin (AY121114) and the Arno river (HM622600), differed by a single point mutation from the German sequence. Two additional, slightly more dissimilar haplotypes (AY121115-6; Pedraza-Lara et al. 2010) differed by two point mutations. These were recorded in northern and central Italian river basins (Po, Tiber) but one of them (AY121115) also in Spain (in Duero, Ebro, Ebroll and Guadalquivir river basins). All of the obtained sequences were deposited to GenBank (A. 'italicus': KP712872-3, A. pallipes s. str.: KP712871, KP712874-5). 


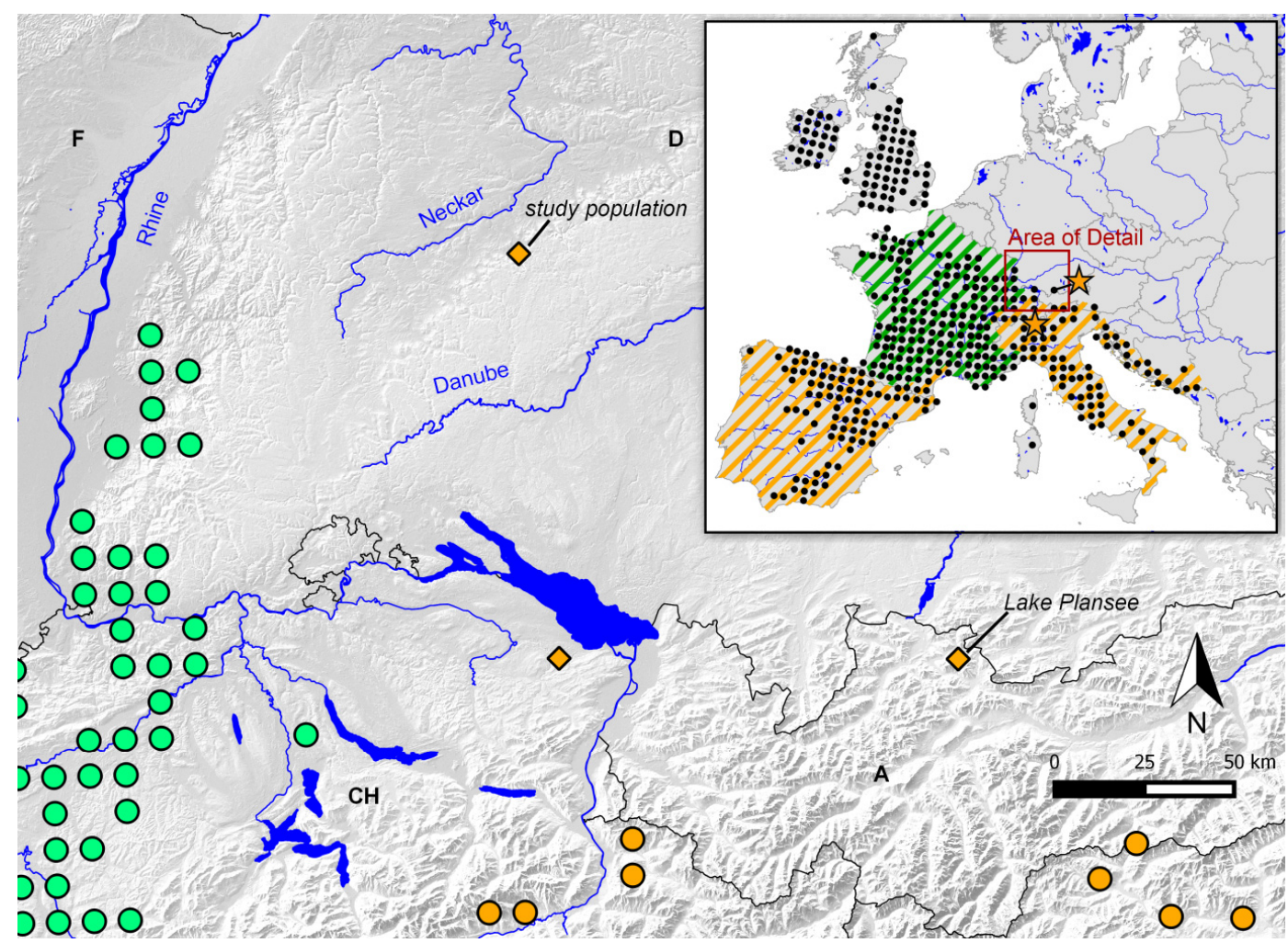

\section{Figure 3}

Location of the study population and distribution of white-clawed crayfish in southwestern Germany and neighbouring territories shown as presence in $10 \times 10 \mathrm{~km}$ grid cells (EEA reference grid), based on Lörtscher et al. (1997), Chucholl and Dehus (2011), Stucki and Zaugg (2011) and Amt für Jagd und Fischerei (2014). Fill colour indicates the genetic clade (green: western lineage, orange: southern lineage) and symbol type indicates either native (circle) or introduced status (diamond). Hatched areas in the upper right panel highlight the assumed native range of the white-clawed crayfish species complex (green: western lineage, orange: southern lineage; according to Grandjean et al., 2000; 2002). Dots indicate confirmed presence in $50 \times 50 \mathrm{~km}$ grid cells (according to Kouba et al., 2014). White-clawed crayfish in the UK and Ireland belong to the western lineage. The stars indicate the origin of the closest matching haplotypes in GenBank (0\% divergence).

\section{DISCUSSION}

Both the tentative morphological identification and the conclusive analysis of mtDNA markers confirm that the newly discovered crayfish belong to the A. 'italicus' clade, a lineage of white-clawed crayfish non-native to Germany. The nearest occurrences of $A$. 'italicus' are known from St Gallen, Switzerland and Tyrol, Austria (Figure 3). Both of these occurrences also originate from introductions, as A. 'italicus' is usually absent from the Rhine and Danube catchments (with the exception of the headwaters of the Alpenrhein catchment in Switzerland; cf. Figure 3). The Swiss population inhabits a pond and is therefore presumably small (Stucki and Zaugg, 2011). The A. 'italicus' occurrence in Tyrol, by contrast, inhabits a natural lake of glacial origin (Lake Plansee) where the species has built up a huge population since its introduction at the beginning of the 20th century (Füreder and Machino, 1995; Sint et al., 2006). Lake Plansee is popular for various recreational activities and attracts many people from Germany. Among recreational divers, the lake is known for its abundant crayfish population (C. Chucholl, pers. obs.). Most interestingly, however, the German lake was reportedly stocked with freshwater mussels (Anodonta spp.) from Lake Plansee soon after its construction in the late 1970s. Illegal deliberate or accidental introduction of A. 'italicus' on that occasion appears likely. 
Based on morphological characteristics reported by Albrecht (1982) and close historical trade affiliations with Tyrol, Füreder and Machino (1995) suspect the Lake Plansee population to originate from the north Italian provinces of Trento or Bolzano. This view was later supported through genetic evidence by Baric et al. (2005), who concluded that an Italian origin of the Lake Plansee population seems very likely. The $16 \mathrm{~S}$ sequences from our German specimens completely matched those from northern Italy as well as from Lake Plansee in Austria. Thus, a common origin of the Lake Plansee population and the German population seems likely, and the results are in accordance with the presumed introduction of the founding specimens from Lake Plansee into Germany.

Irrespective of their provenance, our study conclusively identified the newly discovered crayfish as A. 'italicus'. As opposed to the western clade, this southern clade of white-clawed crayfish does not naturally occur north of the Alps (Figure 3). A. 'italicus' may therefore be considered a non-native taxon in Germany. Preliminary risk assessment suggests little potential for spread and no ecological harm, though. The crayfish are unlikely to spread invasively from the present occurrence, and we suggest that the population should not be subjected to control measures for the time being. However, further dispersal of animals from this population to other German localities is undesirable.

\section{ACKNOWLEDGEMENTS}

We are in debt to F. Cani and F. Wendler for their kind support with collection of crayfish. Moreover, we are grateful to T. Stucki for valuable advice on white-clawed crayfish in Switzerland and three anonymous reviewers for valuable comments that helped to improve the manuscript. Molecular analyses were funded by the Czech Science Foundation (project No. P505/12/0545). The views expressed in this article are those of the authors and not necessarily those of their parent organizations.

\section{REFERENCES}

Albrecht H., 1982. System der europäischen Flusskrebse (Decapoda, Astacidae): Vorschlag und Begründung. Mitt. Hamb. Zool. Mus. Inst., 79, 187-210.

Amt für Jagd und Fischerei, 2014. Der Dohlenkrebs in Südtirol. Südtiroler Fischerzeitung, 1, 14-16.

Baric S., Höllrigl A., Füreder L. and Dalla Via J., 2005. Mitochondrial and microsatellite DNA analyses of Austropotamobius pallipes populations in South Tyrol (Italy) and Tyrol (Austria). Bull. Fr. Pêche Piscic., 376-377, 599-612.

Bertocchi S., Brusconi S., Gherardi F., Buccianti A. and Scalici M., 2008a. Morphometrical characterization of the Austropotamobius pallipes species complex. J. Nat. Hist., 42, 31-32.

Bertocchi S., Brusconi S., Gherardi F., Grandjean F. and Souty-Grosset C., 2008b. Genetic variability of the threatened crayfish Austropotamobius italicus in Tuscany (Italy): implications for its management. Fund. Appl. Limnol., 173, 153-164.

Chiesa S., Scalici M., Negrini R., Gibertini G. and Nonnis Marzano F., 2011. Fine-scale genetic structure, phylogeny and systematics of threatened crayfish species complex. Mol. Phylogenet. Evol., 61, $1-11$.

Chucholl C. and Dehus P., 2011. Dohlenkrebs. In: Chucholl C. and Dehus P. (eds.), Flusskrebse in BadenWürttemberg, FFS, Langenargen, 39-42.

Folmer O., Black M., Hoeh W., Lutz R. and Vrijenhoek R., 1994. DNA primers for amplification of mitochondrial cytochrome c oxidase subunit I from diverse metazoan invertebrates. Mol. Mar. Biol. Biotechnol., 3, 294-299.

Fratini S., Zaccara S., Barbaresi S., Grandjean F., Souty-Grosset C., Crosa G. and Gherardi F., 2005. Phylogeography of the threatened crayfish (genus Austropotamobius) in Italy: implications for its taxonomy and conservation. Heredity, 94, 108-118.

Füreder L. and Machino Y., 1995. Record of the white-clawed crayfish Austropotamobius pallipes (Lereboullet 1858) from Plansee (Tyrol, Austria). Ber. Nat.-Med. Ver. Innsbruck, 82, 241-248. 
Ghia D., Nardi P.A., Negri A., Bernini F., Bonardi A., Fea G. and Spairani M., 2006. Syntopy of $A$. pallipes and A. italicus: genetic and morphometrical investigations. Bull. Fr. Pêche Piscic., 380-381, $1001-1018$.

Grandjean F., Harris D.J., Souty-Grosset C. and Crandall K.A., 2000. Systematics of the European endangered crayfish species Austropotamobius pallipes (Decapoda: Astacidae). J. Crustacean Biol., 20, 522-529.

Grandjean F., Frelon-Raimond M. and Souty-Grosset C., 2002. Compilation of molecular data for the phylogeny of the genus Austropotamobius: one species or several? Bull. Fr. Pêche Piscic., 367, 671-680.

Kouba A., Petrusek A. and Kozák P., 2014. Continental-wide distribution of crayfish species in Europe: update and maps. Knowl. Managt. Aquat. Ecosyst., 413, 05.

Largiadèr C.R., Herger F., Lörtscher M. and Scholl A., 2000. Assessment of natural and artificial propagation of the white-clawed crayfish (Austropotamobius pallipes species complex) in the Alpine region with nuclear and mitochondrial markers. Mol. Ecol., 9, 25-37.

Lörtscher M., Stucki T.P., Clalüna M. and Scholl A., 1997. Phylogeographic structure of Austropotamobius pallipes populations in Switzerland. Bull. Fr. Pêche Piscic., 347, 649-661.

Matallanas B., Ochando M.D., Vivero A., Beroiz B., Alonso F. and Callejas C., 2011. Mitochondrial DNA variability in Spanish populations of $A$. italicus inferred from the analysis of a COI region. Knowl. Manag. Aquat. Ecosyst., 401, 30.

Palumbi S.R., Martin A., Romano S., MacMillan W., Stice L. and Grabowski G., 1991. The simple fool's guide to PCR (Ver.2). University of Hawaii Press, Honolulu, 45 p.

Pedraza-Lara C., Alda F., Carranza S. and Doadrio I., 2010. Mitochondrial DNA structure of the Iberian populations of the white-clawed crayfish, Austropotamobius italicus italicus (Faxon, 1914). Mol. Phylogenet. Evol., 57, 327-342.

Sint D., Dalla Via J. and Füreder L., 2006. The genus Austropotamobius in the Ausserfern region (Tyrol, Austria) with an overlap in the distribution of $A$. torrentium and $A$. pallipes populations. B. Fr. Pêche Piscic., 380-381, 1029-1040.

Souty-Grosset C., Holdich D.M., Noel P.Y., Reynolds J.D. and Haffner P. (eds.), 2006. Atlas of Crayfish in Europe, Museum national d'Histoire naturelle, Paris, Patrimoines naturels, 64, $187 \mathrm{p}$.

Stucki P. and Zaugg B., 2011. Aktionsplan Flusskrebse Schweiz. Bundesamt für Umwelt. UmweltVollzug Nr. 1104, BAFU, Bern, 61 p.

Trontelj P., Machino Y. and Sket B., 2005. Phylogenetic and phylogeographic relationships in the crayfish genus Austropotamobius inferred from mitochondrial COI gene sequences. Mol. Phylogenet. Evol., 34, 212-226.

Zaccara S., Stefani F., Galli P., Nardi P.A. and Crosa G., 2004. Taxonomic implications in conservation management of white-clawed crayfish (Austropotamobius pallipes) (Decapoda, Astacidae) in Northern Italy. Biol. Conserv., 120, 1-10.

Cite this article as: C. Chucholl, A. Mrugała, A. Petrusek, 2015. First record of an introduced population of the southern lineage of white-clawed crayfish (Austropotamobius 'italicus') north of the Alps. Knowl. Manag. Aquat. Ecosyst., 416, 10. 